\section{US Student Mobility Trends in a Global Context}

\section{RAJIKA BHANDARI}

Rajika Bhandari is deputy vice-president, research and evaluation, Institute of International Education (IIE), New York, US. E-mail: rbhandari@iie.org.

$\mathrm{T}^{\mathrm{s}}$ The demand for a US higher education among students across the world has grown steadily, with the United States hosting almost a million students from over 200 countries. In past years, much of the growth has been driven by Chinese undergraduate students, which has shifted the balance between international graduate and undergraduate students in the United States. Significant growth has also been driven by large-scale government scholarship programs that have sent their citizens to the United States primarily to study intensive English or pursue nondegree study in the STEM fields. Overall, the demand for a STEM education remains high, with most international students in the United States opting to pursue a STEM degree while also taking advantage of the 29-month poststudy Optional Practical Training. Against the backdrop of these overall trends, this article examines key developments currently shaping the mobility landscape in the United States and globally.

\section{National Scholarship Programs: Growth or Demise?}

National scholarship programs continue to drive growth in student mobility, but also raise important questions about the sustainability of investments in international education and exchanges. Many US institutions have come to rely on Saudi and Brazilian students and the resources they bring, and the waxing and waning of these programs will likely create a vacuum. For the US higher education sector at large, the question will be how to sustain the links that have been forged as a result of these programs, and how to adjust their enrollment strategies to account for fewer Brazilian and Saudi students. For the sending countries that now have a sizeable number of their youth that have been educated in the United States, the question remains as to how this globally trained talent will be absorbed into the labor economy and what the long-term impacts are of such significant investments.

\section{Global Student Mobility: Some Grave Concerns}

Gender disparity: While an increasing number of women are globally mobile, sending and receiving countries need to work harder to close the international education gender gap, particularly in certain fields of study. The gender gap in the numbers of male and female international students coming to the United States had narrowed significantly over the past three decades, but has widened again over the past two years. This probably has to do with more international students from male-dominated societies where women have traditionally not been encouraged to study abroad. But it also attributable to the increase of international students pursuing STEM fields, which have historically been maledominated fields. Governments and institutions in key sending countries need to encourage more women to go abroad through their scholarship and exchange programs; US institutions, particularly those that attract larger numbers of international students in STEM, need to consider how they can attract more female international students to their programs.

Academic displacement: Beginning in 2015, the world has seen human displacement on a scale unknown in more than a generation, and those displaced face challenges in preparing for or accessing higher education. According to estimates from IIE, in Syria alone, well over I0०,000 university students and as many as 2,000 university professionals are living amongst the refugee population, with their studies and academic careers interrupted indefinitely. In 20I5, 2I.3 million refugees were registered with the United Nations; half of them are under the age of I8 and have yet to enter tertiary education, and many others have experienced a disruption of their higher education studies. Only I percent of all college-age refugees are enrolled in higher education in comparison with 34 percent of tertiarylevel age youth worldwide. Cost of tuition and travel, unavailability of identification and academic documents, lack of recognition of prior studies, language barriers, pressure to assume work or family responsibilities, host community discrimination, and difficulty obtaining information all limit access to education. While efforts are being made to provide financial and application support and to utilize technology to reach displaced students, the need remains great and is expected to continue for some time.

Equity and access in mobility: The adoption of the United Nations' Sustainable Development Goals (SDGs) in 2015 has brought a renewed focus to the critical issues of equity and access in higher education as well as international higher education, and the availability of a global experience to a diversity of students. Scholarship programs funded by governments and private foundations such as the Ford Foundation and the Mastercard Foundation often aim to provide international fellowships to marginalized individuals from developing countries. Research has shown that these types of targeted efforts have a significant impact in increasing access to international education, and can have a multiplier effect on communities and countries. An- 
other aspect of the equity equation is that of brain drain and the loss of trained human capital. While many regions of the world that see large outbound ratios of their college-age population (such as Asia) have begun to see a shift toward "brain circulation," with many of their foreign-educated citizens returning home, Africa continues to experience a significant loss of human capital through student mobility. This raises the issue of what obligations and responsibilities the international higher education sector and industry have toward balancing the needs of developing countries to retain their critical human capital, against the needs and aspirations of individuals to seek the best education possible regardless of where it is offered. This imbalance is addressed to some extent by scholarships in the form of development aid, awarded to students from developing countries by the governments of developed countries and monitored under Target 4. b of the SDGs. But according to a recent analysis of globally available scholarship data by IIE, the total number of such scholarships is small and serves only I percent of those from the developing world who seek a global education.

\section{National scholarship programs con- tinue to drive growth in student mobil- ity, but also raise important questions about the sustainability of investments in international education and exchang-} es.

\section{An Altered Political Climate and the Future OF MOBILITY}

One of the most significant developments over the past two years has been the rise of nationalism around the world, and what is perceived as a turning inward of many traditional host destinations that have typically attracted large numbers of students and scholars from around the world. The first such development was "Brexit" in the United Kingdom in 20I6, which will likely have far-reaching consequences on student mobility into and out of the United Kingdom, and also on mobility between the United Kingdom and continental Europe. Similarly, political shifts in the United States and two travel bans against individuals from seven countries in January and March 2017 have raised many questions about whether the United States remains an attractive destination for international students.

While there is much speculation about this issue and the scale of impact on student mobility to the United States, a recently released snapshot survey (March, 20I7) conducted by AACRAO (the American Association of Collegiate Registrars and Admaissions Officers) in partnership with IIE, the College Board, NAFSA, and NACAC (National Association for College Admissions Counseling, and international ACAC), indicates that 39 percent of 250 responding US campuses report declines in applications from international students, particularly from the Middle East. Declines were also reported from India and China at both the undergraduate and graduate levels. It should be noted that while this survey provides some much-needed information during a period of uncertainty, it is a snapshot based on a modest pool of responding institutions.

What is critical is that the current developments in the United States have mobilized the international education community-including higher education institutions and associations - to develop joint strategies and outreach to underscore the value of international education even further. US institutions have launched coordinated efforts to emphasize to international students that they are still welcome through the \#YouAreWelcomeHere campaign and other similar initiatives.

DOI: http://dx.doi/org/Io.6oI7/ihe.20I7.90.9756

\section{China and International Student Mobility}

\section{Hang Gao and Hans de Wit}

Hang Gao is a PhD candidate in the Faculty of Education, Beijing Normal University (BNU), China, and is currently a visiting scholar at the Center for International Higher Education at Boston College, US. E-mail: gaohang@mail.bnu.edu.cn. Hans de Wit is professor and director of CIHE. E-mail: dewitj@bc.edu.

Future competition in the global knowledge economy 1 will be based on the availability of talents. There is a clear trend that countries around the world look strategically into improving their domestic higher education systems, to become more attractive to talented international students. As the largest developing country and one of the most significant actors in the global economy, China needs to reform critical aspects of its current system and provide better services to international students, to enhance its cultural soft power as well as consolidate its international posi- 